\title{
A study on haematology and serum biochemistry of wattled and non wattled Red
} Sokoto does and their offspring

*Kolo, P. S., Otu, B., Banjo, A. A., and Kolo, H. N.

Department of Animal Production, Federal University of Technology,

Minna, Niger State, Nigeria.

Corresponding author: kolo.philip@futminna.edu.ng; +2347035071871

Abstract

Wattle is of utmost ornamental importance for courting potential mates and influencing thermoregulatory mechanisms which help the animal adapt to the environment. It also provides information on relationship between haematological and serum biochemical parameters. A study on haematology and serum biochemistry of wattled and non wattled Red Sokoto does and their offspring was carried out at the Teaching and Research Farm of the Department of Animal Production, Federal University of Technology, Minna. Fifty (52) Red Sokoto goats comprising of thirty-two (32) does four (4) bucks and sixteen (16) weaned kids managed semi-intensively were used for the study Blood samples were collected using $5 \mathrm{ml}$ syringe and 22-guage needle from the jugular vein. $5 \mathrm{ml}$ of blood was collected from each goat used out of which $2.5 \mathrm{ml}$ was dispensed into Ethylene Diamine Tetra Acetic Acid (EDTA) bottle while the remaining $2.5 \mathrm{ml}$ was dispensed into plain (anticoagulant free) bottles and labelled properly according to the treatment group. Data collected were analyzed using SAS statistical package. It was observed: that wattle had significant effect $(p<0.05)$ on Mean Corpuscular Haemoglobin (MCH), Mean Corpuscular Haemoglobin Concentration $(\mathrm{MCHC})$, White Blood Cell (WBC), Sodium, Potassium, Calcium, Chloride, Phosphorus, Cholesterol, Total Protein, Low Density Lipoprotein (LDL) and Total Bilirubin of Red Sokoto Does but had no significant influence on the haematology and serum biochemistry of wean Red Sokoto kids. Does in $\mathrm{T}_{3}$ had the highest $\mathrm{MCH}$ values of $63.50 \mathrm{mmo} / 1$ while treatments $\mathrm{T} 1$, $\mathrm{T} 2$ and T4 had values of $23.00 \mathrm{mmo} / 1,33.00 \mathrm{mmo} / 1$ and $34.00 \mathrm{mmo} / 1$ respectively. Also Does in T2, T3 and T4 recorded higher calcium levels of $2.54 \mathrm{mmo} / 1,2.56 \mathrm{mmol} / 1$ and $2.61 \mathrm{mmo} / 1$ ) respectively compared to values of $2.29 \mathrm{mmo} / 1$ recorded in $\mathrm{T} 1$. These relevant influence of wattle therefore should suggest the deployment of deliberate effort to preserve the wattle gene to prevent the goats carrying the gene from going to extinction.

Keywords: Wattle, Red Sokoto, Doe, Kids, Haematology.

Une étude sur l'hématologie et la biochimie sérique de chèvres Sokoto femelles rouge et de leur progéniture

\section{Résumé}

L'acacia est de la plus haute importance ornementale pour courtiser les partenaires potentiels et influencer les mécanismes de thermorégulation qui aident l'animal à s'adapter à l'environnement. Il fournit également des informations sur la relation entre les paramètres hématologiques et biochimiques sériques. Une étude sur l'hématologie et la biochimie sérique des femelles de chèvres Sokoto femelle rouge et de leur progéniture a été réalisée à la Ferme d'enseignement et de recherche du Département de la production animale, Université fédérale de technologie, Minna. Cinquante (52) chèvres Sokoto femelle rouges comprenant trente-deux (32) femelles quatre (4) mâles et seize (16) chevreaux sevrés gérés de manière semi-intensive ont été utilisés pour l'étude. Des échantillons de sang ont été prélevés à l'aide d'une seringue de $5 \mathrm{ml}$ et d'une aiguille de calibre 22 de la veine jugulaire. $5 \mathrm{ml}$ de sang ont 
été collectés sur chaque chèvre utilisée, dont 2,5 ml ont été distribués dans un flacon d'acide éthylène diamine tétra acétique (le 'EDTA') tandis que les $2,5 \mathrm{ml}$ restants ont été distribués dans des flacons simples (sans anticoagulant) et étiquetés correctement selon le groupe de traitement. Les données collectées ont été analysées à l'aide du progiciel statistique 'SAS'. Il a été observé : que l'acacia avait un effet significatif $(p<0,05)$ sur l'hémoglobine corpusculaire moyenne (le 'MCH'), la concentration moyenne d'hémoglobine corpusculaire (le 'MCHC'), les globules blancs (GB), le sodium, le potassium, le calcium, le chlorure, le phosphore, le cholestérol, Protéine, lipoprotéine de faible densité (LDL) et bilirubine totale de chèvres Sokoto femelle rouges mais n'ont eu aucune influence significative sur l'hématologie et la biochimie sérique des enfants sevrés Red Sokoto. Les lapins de T3 avaient les valeurs 'MCH' les plus élevées de 63,50 mmo / l tandis que les traitements T1, T2 et T4 avaient des valeurs de 23,00 mmo /l, 33,00 mmo / l et 34,00 mmo/l respectivement. En T2, T3 et T4 ont également enregistré des taux de calcium plus élevés de 2,54 mmo / l, 2,56 mmol / l et 2,61 mmo / l) respectivement par rapport aux valeurs de 2,29 mmo / l enregistrées en T1. Ces influences pertinentes de l'acacia devraient donc suggérer le déploiement d'efforts délibérés pour préserver le gène de l'acacia afin d'éviter que les chèvres porteuses du gène ne s'éteignent.

Mots clés: des chevres sokoto rouges femelles, kids, Hematologie.

\section{Introduction}

Wattle is the cartilaginous tissue surrounded by dense fibrous connective tissue hanging on the neck of some ruminants (Robert, 1994). Wattle possession in goats could either be present or absent. When present, it could vary in number, shape and position. It is speculated that the expression of wattle traits in goats may represent some adaptive mechanisms related to adaptation and survival in different ecological zones (Odubote, 1994). Several research findings (Casu et al., 1970; Osinowo et al., 1988; Shongjia et al., 1992 and Ozoje and Mgbere, 2002) have reported some positive associations between wattle traits and livestock performances, namely; growth, reproduction and heat tolerance in West African Dwarf goats. (Adedeji et al., 2011) reported the influence of Haematological and serum biochemical parameters by the presence or absence of wattle. Wattle genes also had significant influence on White Blood Cell (WBC), Red Blood Cell (RBC), serum potassium concentration and Haemoglobin. The author reported that Goats with bilateral wattle had higher red blood cell counts of $12.66 \pm 0.05 \times 106 / \mu 1$, haemoglobin conctration of $9.08 \pm 0.06 \mathrm{~g} / \mathrm{dl}$ and white blood cell counts of $11.69 \pm 0.04 \times 103 / \mu 1$. Goats with unilateral wattle however had the lowest RBC while goats with no wattle had the lowest in WBC and $\mathrm{Hb}$. Information on effect of wattle on Red Sokoto breed of Nigeria, especially on the role of wattle on, haematology and serum biochemistry of Red Sokoto goat is scarce. This research is focused at evaluating the influence of wattle on, haematology and serum biochemistry of Red Sokoto (Maradi) does and their off spring.

\section{Materials and methods \\ Description of study area}

The study was carried out at the Teaching and Research Farm of the Department of Animal Production, Federal University of Technology, Minna, Niger State, Nigeria. Minna is in the Southern Guinea Savannah vegetation belt of Nigeria within latitude $9^{\circ}$ $37^{\prime}$ North and longitude $6^{\circ} 33^{\prime}$ East of the equator. The area has a mean annual rainfall of $1,300 \mathrm{~mm}$, with an average highest temperature in the month of March and lowest temperature in the month of August. The mean annual temperature is between 22 to $40^{\circ} \mathrm{C}$ with two distinct seasons; wet from 
March to October and dry from November to March (Federal University of Technology, Minna, Students Handbook, 2017).

Source and management of the experimental animals

Fifty two (52) Red Sokoto goats comprising of thirty-two does, four bucks and sixteen kids were used for theexperiment. The animals were sourced from local farmers and goats markets within Niger State (Minna, Mariga, Beji, Kanfaninbobi and Bida goat markets). The does were seven to eight months old at the time of purchase. The purchased does were acclimatized to the new environment for a period of eight (8) weeks (this was done purposely to allow the does more time for sexual maturity). During acclimatization, the goats were administered with Ivomectin ${ }^{8}$; a broad spectrum anti parasitic drug, to remove both internal and external parasites. Vaccination against peste des petits ruminants (PPR) was done using PPR-VAC ${ }^{\circledast}$. Broad spectrum anti-biotic (20\% oxyteracycline: Heibei Huarun Pharmacy Co. Ltd., China), penstrep $^{\circledR}$ (Kepro, Holland), envite ${ }^{\circledR}$ multi vitamin (Ventidia pharmaceutical Ltd, India), albendazole ${ }^{\circledR}$ (Jawa International Limited, Lagos, Nigeria) and other drugs were administered when necessary to keep the animals in good health. The pen was constructed from wood and metal sheets. Water were provided ad-libitum, feed (yam peels, maize offal, beans husk and sorghum chaff) were given around 9 am every morning at the rate of $10 \mathrm{~kg}$ per treatment before the animals were released for grazing. The proximate composition of feeds given to the goats is shown in Table 1 . During acclimatization, the goats were administered with Ivomectin ${ }^{\circledR}$.

Table 1. Proximate composition of the experimental feeds

\begin{tabular}{lllll}
\hline Parameters & Yam peel & Maize offal & Beans husk & Sorghum chaff \\
\hline Dry matter (\%) & 91.09 & 86.05 & 87.58 & 89.28 \\
Crude protein (\%) & 7.87 & 14.87 & 8.75 & 6.12 \\
Crude fibre (\%) & 11.70 & 13.10 & 32.45 & 32.90 \\
Ether extract (\%) & 1.70 & 2.20 & 1.60 & 5.88 \\
Ash (\%) & 4.80 & 0.95 & 8.51 & 4.21 \\
Nitrogen Free Extract (\%) & 65.02 & 54.93 & 36.27 & 40.17 \\
Metabolizable Energy (Kcal/g) & 307.66 & 299.09 & 194.48 & 238.08 \\
\hline
\end{tabular}

Proximate composition carried out at Animal Production Laboratory F.U.T Minna

Treatments and experimental design

After parturition, the thirty-two does and their kids (sixteen) were allotted to four treatments in a Completely Randomised Design (CRD). Treatment one $\left(\mathrm{T}_{1}\right)$ comprised of goats without wattles in both sexes (serving as the control). Treatment two $\left(\mathrm{T}_{2}\right)$ comprised of does without wattle mated with wattled bucks. Treatment three $\left(\mathrm{T}_{3}\right)$ comprised of wattled does mated with non-wattled bucks while Treatment four $\left(\mathrm{T}_{4}\right)$, comprised of wattled bucks and does. Each treatment had eight does. The four bucks (one buck per treatment) used for mating the does were kept separately from the does. The animals were tagged properly for identification. For the kids Treatment one (T1) comprised of kids resulting from T1 were both parents had no wattles (control). Treatment two (T2) comprised of kids resulting from does without wattle mated with wattled bucks. Treatment three (T3) comprised of kids resulting from wattled does mated with non-wattled bucks while Treatment four (T4), comprised of kids resulting from wattled bucks and does. The does and kids were raised semi intensively while the bucks were confined (to prevent unwanted breeding). The animals were allowed to graze in the daytime and housed later in the evening after grazing. 


\section{Data collection}

Five millilitres $(5 \mathrm{ml})$ was collected from each experimental goat from the jugular vein using needle and syringe ( $5 \mathrm{ml}$ syringe and 22-guage needle were used). Once the jugular vein was located, a thumb was used to press the lower part of the vein to prevent blood from flowing. Out of the $5 \mathrm{ml}$ of blood collected, $2.5 \mathrm{ml}$ was dispensed into Ethylene Diamine Tetra Acetic Acid (EDTA) bottle and labelled according to the treatment group, while the remaining $2.5 \mathrm{ml}$ was dispensed into plain (anticoagulant free) bottles and were also labelled properly. The blood samples were transported to Falala Rabi Laboratory, Tunga, Minna for analysis for analysis. Blood samples with anticoagulants were used to analyze for the Packed Cell Volume (PCV), Red Blood Cell (RBC), White Blood Cell (WBC) and Haemoglobin (HB) with the aid of Abacus 380, haematology analyzer (Diamond Diagnostics, USA). The clotted blood was used to determine the serum protein, albumin, globulin concentration, creatinine concentration, serum glucose, nitrogen and urea. Others including cholesterol, serum sodium, potassium and serum hepatic enzymes namely Aspatate aminotransferase (AST),
Alanine amino tranferese (ALT) and Alkaline phosphatase (ALP) were analyzed using Chem 5V3 semi-automatic analyzer (Alliance instruments, France).

Data collected on haematology and serum biochemistry were analyzed using SAS statistical package (SAS, 2000). The variations were separated using Duncan Multiple Range Test.

\section{Results}

Effect of wattle on the haematological parameters of Red Sokoto does after birth (Table 2) revealed no significant $(\mathrm{p}>0.05)$ difference in most of the haematological parameters measured for all the does except for white blood cell count (WBC), Mean Corpuscular Haemoglobin (MCH) and Mean Corpuscular Haemoglobin Concentration (MCHC) that showed some level of significance $(p<0.05)$. Does in $T_{3}$ had the highest $(p<0.05) \mathrm{MCH}$ values $(63.50 \mathrm{mmo} / \mathrm{l})$ while those in $\mathrm{T}_{1}(23.00$ $\mathrm{mmo} / \mathrm{l}), \mathrm{T}_{2}(33.00)$ and $\mathrm{T}_{4}$ (34.00) had similar $(p>0.05)$ but lower $(p<0.05)$ values of $\mathrm{MCH}$ compered to does in $\mathrm{T}_{3}(63.50)$. The values of MCHC of does in $\mathrm{T}_{2}(38.00)$ were higher $(p>0.05)$ than in the other treatments. Does in $\mathrm{T}_{4}(17.75)$ had the highest $(\mathrm{p}<0.05)$ white blood cell count compared to does in other treatments.

Table 2: Effect of wattle on the haematological parameters of Red Sokoto does

\begin{tabular}{|c|c|c|c|c|c|c|}
\hline Parameters & $\mathrm{T}_{1}$ & $\mathrm{~T}_{2}$ & $\mathrm{~T}_{3}$ & $\mathrm{~T}_{4}$ & SEM & *Normal range \\
\hline $\mathrm{RBC}\left(\mathrm{x} 10^{12} / \mathrm{L}\right)$ & 10.35 & 10.50 & 10.95 & 10.75 & 1.34 & $8.0-18.0$ \\
\hline $\mathrm{Hb}(\mathrm{g} / \mathrm{dl})$ & 10.40 & 9.40 & 9.75 & 9.70 & 0.55 & $8.0-12.0$ \\
\hline $\operatorname{PCV}(\%)$ & 23.00 & 23.00 & 25.50 & 25.50 & 1.54 & $22-38$ \\
\hline MCV (fl) & 71.00 & 28.00 & 57.50 & 66.00 & 6.01 & $16-25$ \\
\hline $\mathrm{MCH}(\mathrm{pg})$ & $23.00^{\mathrm{b}}$ & $33.00^{\mathrm{b}}$ & $63.50^{\mathrm{a}}$ & $34.00^{\mathrm{b}}$ & 5.86 & $5.2-8.0$ \\
\hline MCHC (g/dl) & $30.50^{\mathrm{b}}$ & $38.00^{\mathrm{a}}$ & $32.00^{\mathrm{b}}$ & $30.00^{\mathrm{b}}$ & 1.52 & $30-36$ \\
\hline WBC $\left(\times 10^{9} / \mathrm{L}\right)$ & $9.20^{\mathrm{b}}$ & $14.20^{\mathrm{ab}}$ & $9.00^{\mathrm{b}}$ & $17.75^{\mathrm{a}}$ & 0.27 & $4.0-13.0$ \\
\hline \multicolumn{7}{|l|}{ WBC differentials } \\
\hline Lymphocytes (\%) & 73.50 & 64.00 & 66.5 & 65.5 & 3.09 & $50-70$ \\
\hline Neutrophils (\%) & 13.50 & 15.00 & 21.5 & 26.35 & 4.55 & $30-48$ \\
\hline Eosinophils (\%) & 8.40 & 21.00 & 7.6 & 5.5 & 2.09 & $1-8$ \\
\hline Monocytes (\%) & 3.60 & 0.00 & 3.45 & 2.15 & 0.57 & $0-4$ \\
\hline Basophils (\%) & 1.00 & 0.00 & 0.95 & 0.5 & 0.11 & $0-1$ \\
\hline \multicolumn{7}{|c|}{$\begin{array}{l}\text { *Daramola et al. }(2005), \text { abcd Means within a row having different superscripts differed sign } \\
\mathrm{T}_{1}=\text { Non-wattled does mated with no wattled bucks } ; \mathrm{T}_{2}=\text { Non-wattled does mated with wattled bucks; } \\
\mathrm{T}_{3}=\text { Wattled does mated with no wattled buck: } \mathrm{T}_{4}=\text { Wattled does mated with wattled bucks. } \mathrm{SEM}=\text { Standard error of } \\
\text { mean, RBC = Red blood cell count, } \mathrm{H} \quad \mathrm{b}=\text { Haemoglobin concentration, } \mathrm{PCV}=\text { Packed cell volume } \\
\mathrm{MCV}=\text { Mean corpuscular volume, MCH = Mean corpuscular haemoglobin, MCHC = Mean corpuscular } \\
\text { haemoglobin concentration, WBC = White blood cell } \mathbf{2 0 0}\end{array}$} \\
\hline
\end{tabular}




\section{Kolo, Otu, Banjo and Kolo}

The Effect of wattle on the serum biochemistry of the Red Sokoto does (Table $3)$ showed significant $(p<0.05)$ difference in the sodium, potassium, calcium, phosphorus, cholesterol, total protein, low density lipoprotein and total bilirubin components of the blood serum of the does. The chloride, urea, creatinine, glucose, high density lipoprotein, albumin, triglyceride, conjugated bilirubin, alanine a minotransferase, a s partate aminotransferase and Alkaline phosphatase showed no significant $(\mathrm{p}>0.05)$ difference across treatments. Does in $\mathrm{T}_{2}(160.10$ $\mathrm{mmo} / \mathrm{l}), \mathrm{T}_{3}(162.04 \mathrm{mmo} / \mathrm{l})$ and $\mathrm{T}_{4}(164.37$ $\mathrm{mmo} / \mathrm{l})$ had significantly $(\mathrm{p}<0.05)$ higher sodium content in blood serum than does in $\mathrm{T}_{1}(144.13 \mathrm{mmo} / \mathrm{l})$. Does in $\mathrm{T}_{1}$ had the highest $(\mathrm{p}<0.05)$ potassium content $(6.04$ $\mathrm{mmo} / \mathrm{l})$ while the least was in $\mathrm{T}_{2}(4.53$ $\mathrm{mmo} / \mathrm{l})$. Does in $\mathrm{T}_{2}(2.54 \mathrm{mmol}), \mathrm{T}_{3}(2.56$ $\mathrm{mmol} / \mathrm{l})$ and $\mathrm{T}_{4}(2.61 \mathrm{mmo} / \mathrm{l})$ had similar $(p>0.05)$ calcium content in the blood serum, but the three had higher $(\mathrm{p}<0.05)$ levels of calcium than does in $T_{1}(2.29$ $\mathrm{mmo} / \mathrm{l})$. Phosphorus content in $\mathrm{T}_{4}(1.93$ $\mathrm{mmo} / \mathrm{l})$ was significantly $(\mathrm{p}<0.05)$ higher while the least was found in $T_{3}$ (1.57 $\mathrm{mmo} / \mathrm{l})$. The cholesterol level of wattled does mated with wattled bucks $\left(\mathrm{T}_{4}\right)$ was significantly $(p<0.05)$ higher $(4.67 \mathrm{mmo} / \mathrm{l})$ than non-wattled does mated with nonwattled bucks in $\mathrm{T}_{2}(2.60 \mathrm{mmo} / \mathrm{l})$. Does in $\mathrm{T}_{2}$ however, had cholesterol values similar $(p>0.05)$ to the values obtainable for does in $\mathrm{T}_{1}(3.77 \mathrm{mmo} / \mathrm{l})$ and $\mathrm{T}_{3}(3.23 \mathrm{mmo} / \mathrm{l})$. Does in $\mathrm{T}_{4}$ had higher $(5.63 \mathrm{~g} / 100 \mathrm{ml})$ total protein in the blood serum than other treatments. Does in $\mathrm{T}_{3}(2.03 \mathrm{mmo} / \mathrm{l})$ and $\mathrm{T}_{4}(2.40 \mathrm{mmo} / \mathrm{l})$ had equal but higher $(\mathrm{p}<0.05)$ levels of low density lipoprotein than does in $\mathrm{T}_{1}(1.10$ $\mathrm{mmo} / \mathrm{l})$ and $\mathrm{T}_{2}(1.23 \mathrm{mmol})$. Does in $\mathrm{T}_{4}(4.81$ $\mathrm{mmo} / \mathrm{l})$ equally had significantly $(\mathrm{p}<0.05)$ higher levels of total bilirubin than does in $\mathrm{T}_{1}(3.08 \mathrm{mmo} / \mathrm{l}), \mathrm{T}_{2}(2.74 \mathrm{mmo} / \mathrm{l})$ and $\mathrm{T}_{3}$ (2.75 mmo/l), respectively. Tables 4 and 5 showed no significant $(\mathrm{p}>0.05)$ difference in haematology and serum biochemistry of the weaned kids.

Table 3: Effect of wattle on the serum biochemistry of the Red Sokoto does

\begin{tabular}{lllllll}
\hline Parameters & $\mathrm{T}_{1}$ & $\mathrm{~T}_{2}$ & $\mathrm{~T}_{3}$ & $\mathrm{~T}_{4}$ & $\mathrm{SEM}$ & *Normal range \\
\hline Sodium (mmo/l) & $144.13^{\mathrm{b}}$ & $160.10^{\mathrm{a}}$ & $162.4^{\mathrm{a}}$ & $164.37^{\mathrm{a}}$ & 1.33 & $124-155$ \\
Potassium (mmo/l) & $6.04^{\mathrm{a}}$ & $4.53^{\mathrm{c}}$ & $4.80^{\mathrm{bc}}$ & $5.66^{\mathrm{ab}}$ & 0.14 & $3.0-6.0$ \\
Calcium mmo/l) & $2.29^{\mathrm{b}}$ & $2.54^{\mathrm{a}}$ & $2.56^{\mathrm{a}}$ & $2.61^{\mathrm{a}}$ & 0.02 & $1.15-3$ \\
Chloride (mmo/l) & 65.93 & 89.80 & 47.38 & 46.32 & 6.36 & $105-120$ \\
Phosphorus (mmo/l) & $1.73^{\mathrm{ab}}$ & $1.73^{\mathrm{ab}}$ & $1.57^{\mathrm{b}}$ & $1.93^{\mathrm{a}}$ & 0.04 & $0.58-4.5$ \\
Urea (mmo/l) & 6.80 & 6.00 & 5.29 & 5.79 & 0.36 & $0.8-9.7$ \\
Creatinine (mg/dl) & 0.76 & 0.53 & 0.55 & 0.60 & 0.04 & $0.9-1.8$ \\
Cholesterol (mmo/l) & $3.77^{\mathrm{b}}$ & $2.60^{\mathrm{c}}$ & $3.23^{\mathrm{bc}}$ & $4.67^{\mathrm{a}}$ & 0.09 & $2.07-3.37$ \\
Glucose (mmo/l) & 1.65 & 2.02 & 1.19 & 1.32 & 0.18 & $2.78-4.16$ \\
Total Protein (g/100ml) & $4.08^{\mathrm{b}}$ & $4.85^{\mathrm{ab}}$ & $5.19^{\mathrm{ab}}$ & $5.63^{\mathrm{a}}$ & 0.19 & $6.3-8.5$ \\
HDL (mmo/l) & 0.76 & 1.01 & 0.95 & 0.95 & 0.08 & $0.9-1.7$ \\
LDL (mmo/l) & $1.10^{\mathrm{b}}$ & $1.23^{\mathrm{b}}$ & $2.03^{\mathrm{a}}$ & $2.40^{\mathrm{a}}$ & 0.10 & $0-4.1$ \\
Albumin (g/100ml) & 2.14 & 2.22 & 2.22 & 2.61 & 0.23 & $2.8-4.3$ \\
Triglyceride (mmo/ litre) & 0.38 & 1.04 & 0.57 & 0.37 & 0.09 & $0.16-1.6$ \\
Total Bilirubin (mg/dl) & $3.08^{\mathrm{b}}$ & $2.74^{\mathrm{b}}$ & $2.75^{\mathrm{b}}$ & $4.81^{\mathrm{a}}$ & 0.04 & $0-0.9$ \\
Conjugated Bilirubin (mm/l) & 2.01 & 1.70 & 1.55 & 1.58 & 0.03 & $0-1.7$ \\
ALT (IU/L) & 14.61 & 14.33 & 19.87 & 13.92 & 1.59 & $12-38$ \\
AST (IU/L) & 8.75 & 13.46 & 9.65 & 5.16 & 1.25 & $2-22$ \\
ALP (IU/L) & 28.83 & 23.54 & 23.67 & 23.54 & 4.00 & $14-25.7$ \\
\hline
\end{tabular}

*Daramola et al. (2005), abcd Means within a row having different superscripts differed significantly $\mathrm{T}_{1}=$ Non-wattled does mated with non -wattled bucks; $\mathrm{T}_{2}=$ Non-wattled does mated with wattled bucks; $\mathrm{T}_{3}=$ Wattled does mat ed with non - wattled buck: $\mathrm{T}_{4}=$ Wattled does mated with wattled bucks. $\mathrm{SEM}=$ Standard error of mean, $\mathrm{HDL}=$ High density lipoprotein, $\mathrm{LDL}=$ Low density lipoprotein $\mathrm{ALT}=$ Alanine aminotransferase, $\mathrm{AST}=$ Aspartate aminotransferase, $\mathrm{ALP}=$ Alkaline phosphatase 
Table 4. Effect of wattle on the haematological parameters of weaned Red Sokoto kids raised semi intensively

\begin{tabular}{lllllll}
\hline Parameters & $\mathrm{T}_{1}$ & $\mathrm{~T}_{2}$ & $\mathrm{~T}_{3}$ & $\mathrm{~T}_{4}$ & $\mathrm{SEM}$ & *Normal range \\
\hline $\mathrm{RBC}\left(\mathrm{x} 10^{12} / \mathrm{L}\right)$ & 5.60 & 5.80 & 5.50 & 5.75 & 0.46 & $8.0-18.0$ \\
$\mathrm{Hb}(\mathrm{g} / \mathrm{dl})$ & 10.20 & 10.70 & 10.45 & 11.30 & 0.57 & $8.0-12.0$ \\
$\mathrm{PCV}(\%)$ & 30.50 & 31.50 & 30.00 & 33.00 & 1.22 & $22-38$ \\
$\mathrm{MCV}(\mathrm{fl})$ & 57.50 & 56.00 & 38.00 & 51.00 & 1.31 & $16-25$ \\
$\mathrm{MCH}(\mathrm{pg})$ & 13.00 & 14.00 & 32.50 & 13.50 & 3.21 & $5.2-8.0$ \\
$\mathrm{MCHC}(\mathrm{g} / \mathrm{dl})$ & 35.50 & 37.00 & 35.00 & 37.50 & 7.95 & $30-36$ \\
WBC (x10\%) & 13.55 & 14.00 & 13.55 & 13.55 & 1.43 & $4.0-13.0$ \\
WBC differentials & & & & & & \\
Lymphocytes (\%) & 51.05 & 49.55 & 45.55 & 47.55 & 1.20 & $50-70$ \\
Neutrophils (\%) & 40.95 & 42.45 & 45.95 & 44.95 & 2.58 & $30-48$ \\
Eosinophils (\%) & 6.50 & 6.50 & 7.00 & 6.00 & 0.62 & $1-8$ \\
Monocytes (\%) & 3.50 & 3.80 & 3.45 & 3.30 & 0.50 & $0-4$ \\
Basophils (\%) & 1.30 & 1.30 & 1.25 & 1.30 & 0.22 & $0-1$ \\
\hline
\end{tabular}

*Daramola et al. (2005), $\mathrm{T}_{1}=$ Non-wattled does mated with non -wattled bucks; $\mathrm{T}_{2}=$ Non-wattled does mated with wattled bucks; $T_{3}=$ Wattled does mated with non -wattled buck: $T_{4}=$ Wattled does mated with wattled bucks. $\mathrm{SEM}=$ Standard error of mean, $\mathrm{RBC}=$ Red blood cell $\mathrm{c}$ ount, $\mathrm{Hb}=$ Haemoglobin concentration, $\mathrm{PCV}=$ Packed cell volume, $\mathrm{MCV}=$ Mean corpuscular volume, $\mathrm{MCH}=$ Mean corpuscular haemoglobin, $\mathrm{MCHC}=$ Mean corpuscular haemoglobin concentration, $\mathrm{WBC}=$ White blood cell

Table 5: Effect of wattle on the serum biochemisty of weaned Red Sokoto kids raised semi intensively

\begin{tabular}{lllllll}
\hline Parameters & $\mathrm{T}_{1}$ & $\mathrm{~T}_{2}$ & $\mathrm{~T}_{3}$ & $\mathrm{~T}_{4}$ & SEM & *Normal range \\
\hline Potassium (mmo/l) & 6.30 & 6.53 & 6.99 & 7.27 & 0.20 & $3.0-6.0$ \\
Calcium mmo/l) & 3.00 & 3.20 & 3.40 & 3.10 & 0.34 & $1.15-2.4$ \\
Chloride (mmo/l) & 99.00 & 101.30 & 98.80 & 105.00 & 1.25 & $105-120$ \\
Phosphorus (mmo/l) & 2.90 & 2.30 & 3.40 & 2.21 & 082 & $0.58-4.5$ \\
Urea (mmo/l) & 7.26 & 7.26 & 8.39 & 9.52 & 0.87 & $0.8-9.7$ \\
Creatinine (mg/dl) & 1.40 & 1.40 & 3.40 & 1.65 & 0.45 & $0.9-1.8$ \\
Cholesterol (mmo/l) & 8.20 & 8.63 & 8.20 & 10.33 & 0.84 & $64.6-136.4$ \\
Glucose (mmo/l) & 4.79 & 6.66 & 6.58 & 5.62 & 0.78 & $6-10$ \\
Total protein (g/100ml) & 6.08 & 6.17 & 6.93 & 7.31 & 0.40 & $6.3-8.5$ \\
HDL (mmo/l) & 0.72 & 0.68 & 0.59 & 0.83 & 0.09 & $0.9-1.7$ \\
LDL (mmo/l) & 1.78 & 1.92 & 1.91 & 3.60 & 0.70 & $0-4.1$ \\
Albumin (g/100ml) & 2.88 & 3.18 & 3.07 & 3.18 & 0.21 & $2.8-4.3$ \\
Triglyceride (mmo/ litre) & 2.54 & 4.20 & 2.54 & 3.58 & 0.72 & $0.16-1.6$ \\
Total bilirubin (mg/dL) & 1.60 & 1.62 & 1.63 & 1.945 & 0.51 & $0-0.9$ \\
ALT (IU/L) & 19.09 & 19.09 & 19.09 & 19.09 & 7.15 & $12-38$ \\
AST (IU/L) & 11.03 & 11.03 & 11.03 & 11.03 & 4.14 & $2-22$ \\
ALP (IU/L) & 23.60 & 23.60 & 44.85 & 27.88 & 7.25 & $1.4-25.7$ \\
\hline
\end{tabular}

*Daramola et al. (2005), $\mathrm{T}_{1}=$ Non-wattled does mated with non-wattled bucks; $\mathrm{T}_{2}=$ Non-wattled does mated with wattled bucks; $\mathrm{T}_{3}=$ Wattled does mated with non-wattled buck: $\mathrm{T}_{4}=$ Wattled does mated with wattled bucks. SEM= Standard error of mean, HDL= High density lipoprotein, LDL = Low density lipoprotein, $\mathrm{ALT}=$ Alanine aminotransferase, $\mathrm{AST}=$ Aspartate aminotransferase, $\mathrm{ALP}=$ Alkaline phosphatase

The haematology of the does (Table 2) shows that the MCH of does were far above the range given by Daramola et al. (2005) for West African Dwarf goats. The higher levels of MCH obtained in this study could be due to the age and breed difference between the Red Sokoto breeds used in this work and the West African Dwarf goats used by Daramola et al. (2005). Osinowo et al. (1988) suggested that breed difference appear to modify the effect of wattle. Arfuso et al. (2016) also stated that haematological 


\section{Kolo, Otu, Banjo and Kolo}

indicies in healthy goats show some difference in relation to breed and age. The higher $\mathrm{MCH}$ of wattled does mated with non-wattled bucks $\left(\mathrm{T}_{3}\right)$ might probably be because of the increased activity of bone marrow and deficiency of some haemopoietic factors. $\mathrm{MCH}$ is one of the haematological parameters listed in the diagnosis of anaemia and also act as a useful guide to reveal the capacity of the bone marrow to produce red blood cells, aside MCV and MCHC (Awodi et al., 2005; Bishnu, 2016). The MCHC values obtained in this study agrees with those given by Daramola et al. (2005) for West African Dwarf goats except for non-wattled does mated with wattle bucks $\left(T_{2}\right)$. This may be due to anaemia or an increase in the activity of the bone marrow. Awodi et al. (2005) and Etim (2013) listed MCHC as one of the important haematological parameters for the diagnosis of anaemia and serve as a useful index of the capacity of bone marrow to produce red blood cells.

The WBC in $T_{1}$ (non-wattled does mated with non-wattled bucks) and $T_{3}$ (wattled does mated with wattled bucks) were within the range given by Daramola et al. (2005) while those in $\mathrm{T}_{2}$ (non-wattled does mated with wattled bucks) and $T_{4}$ (wattled does mated with wattled bucks) were not within the range. Does in $\mathrm{T}_{4}$ (wattled does mated with wattle bucks) were observed to have the highest WBC (above the range). This may be due to the presence of infection or a toxic substance in the body of the does. Higher WBC is an indicator of immune response to illnesses or diseases or toxin in an organism (Bradbury et al., 1999). According to Etim (2013), over the upper limits of white blood cell (leukocytosis) indicates problem; these could include: stress, infection, allergy, inflammation, trauma, or certain diseases. Therefore, elevated levels of white blood cell count need further investigation. Braun (2013) stated that high white blood cell count might be as a result from stress, disorder in the immune system, and infection. It was also reported in other studies that high number of leucocytes may be due to infectious diseases, bone marrow tumour, anaemia, severe physical stress, inflammatory disease or tissue damage (example, burns) (Bagby, 2007; Dugdale, 2011). The significant effect of wattle on haematological parameters $(\mathrm{MCH}, \mathrm{MCHC}$ and WBC) is in line with the observations of Adedeji et al. (2011) who stated that wattle had significant influence on RBC, WBC, $\mathrm{Hb}$, and $\mathrm{K}^{+}$of West African Dwarf goats.

The serum biochemistry of does (Table 3 ) revealed that $\mathrm{T}_{2}$ (non-wattled does mated with wattled bucks), $\mathrm{T}_{3}$ (wattled does mated with non-wattled bucks) and $\mathrm{T}_{4}$ (wattled does mated with wattle bucks) had higher and above the normal range values for sodium. This may be due to harmattan wind or the hot environmental temperature of Minna during October month. James (2018) stated that high level of sodium in blood (hypernatremia) could be caused by dehydration, which could be because of many reasons which includes: not drinking enough liquid, diarrhoea and kidney dysfunction. This could cause the animals to be thirsty and in worse cases, may cause confusion, muscular twitches and seizures.

Does in $\mathrm{T}_{1}$ (non-wattled does mated with non-wattled bucks) had higher serum potassium while does in the other treatments were within the normal range given by Daramola et al. (2005). Mayo Clinic (2019) stated that hyperkalemia could be as a result of the rupture of blood cells in the blood samples shortly after blood collection. The ruptured cells leak their potassium into the sample, thereby raising the amount of potassium in the sample. Since kidney dysfunction was not suspected, focus is shifted to the rupture of blood cells in the samples collected. Does in $\mathrm{T}_{2}$ (non-wattled does mated with wattled bucks), $\mathrm{T}_{3}$ (wattled does mated with non- 
wattled bucks) and $\mathrm{T}_{4}$ (wattled does mated with wattled bucks) had the highest calcium levels. Calcium is an essential mineral needed for bone and teeth health, regulating certain body processes such as squeezing and relaxing muscles, sending and receiving nerve signals, keeping a normal heartbeat, releasing hormones and other chemicals, and clotting blood (Bayer, 2018; Preserved Articles 2018; Nemours Foundation, 2018; Medline Plus, 2018). Does in $\mathrm{T}_{4}$ (wattled does mated with wattled bucks) had the highest phosphorus in the blood serum. The body requires phosphorus for proper nerve functioning, building and repairs of bones and teeth and helps muscluar contraction (Chemocare, 2019). Does in $\mathrm{T}_{4}$ (wattled does mated with wattled bucks) and $\mathrm{T}_{1}$ (non-wattled does mated with non-wattled bucks) had higher levels of cholesterol and this put the does in these treatments at a higher risk of heart diseases (Mayo Clinic 2019). Although the total protein was within the normal range given by Daramola et al. (2005), does in $\mathrm{T}_{4}$ (wattled does mated with wattled bucks) had higher levels. This may be caused by a particular condition or symptom, as certain blood proteins elevate as the body fight infection or inflammations (Mayo Clinic, 2019). The total bilirubin levels in all the treatments had higher range of bilirubin than the ones given by Daramola et al. (2005) which indicates that the red blood cells are being breaken down at an abnormal rate or the liver is not breaking down waste properly and clearing the bilirubin from the blood.

\section{Conclusion}

The relevant influence of wattle on haematology and serum biochemical indicators in Red Sokoto goats should therefore suggest the deployment of deliberate efforts to preserve the wattle gene thus preventing the goats carrying the gene from going to extinction. More so, the study has provided a template that will assist in facilitating improvement of performance of Red Sokoto goats through selection using wattle as biomarkers.

\section{References}

Adedeji, T. A., Ozoje, M.O., Peters, S.O., Sanusi, O.A., Ojedapo, L. O. \& Ige, A. O. (2011). Coat pigmentation and Wattle Genes' effect on some Haematological Characteristics of Heat Stressed and Extensively Reared West African Dwarf Goats. World Journal of Life Science and Medical Research, 1(3), 48-55.

Arfuso, F., Fazio, F., Rizzo, M., Marafioti, S., Zanghì, E. \& Piccione1, G. (2016). Factors Affecting the Hematological Parameters in Different Goat Breeds from Italy. Annal of Animal Science, 16(3), 743-757.

Awodi, S, Ayo, J. O, Atodo, A. D. \& Dzende, T. (2005). Some Haematological Parameters and the Erythrocyte Osmotic Fragility in the Laughing Dove (Streptopella senegalensis) and the village weaver bird (Ploceus scucullatus). In: Chineke, C. A;

Bagby, G. C. (2007). Leucopenia and leucocytosis. In: Goldman L. Ausiello D. (eds). Cecil Medicine, 23rd edition. Philadelphia. Pa: Saunders Elsevier, 173.

Bayer (2018) Importance of Calcium - Go Deeper for Bone Health. http://www.bayer.us/en/csr-andsustainability/transparency-insupply-chains/. Retrieved 12 December, 2018

Bishnu, C. P. (2016). Evaluation of haematological and biochemical parameters of goats of Central Odisha environment fed on natural grazing land of Odisha, India. The 
Pharma Innovation Journal, 5(5), 83-90.

Bradbury, M. G, Egan, S. V. \& Bradbury, J. H. (1999). Determination of all forms of cyanogen in cassava roots and cassava products using picrate paper kits. Clinical cases of small ruminants in Zaria, Nigeria. Bulletin of Animal Heath and Production in Africa, 30, 111-116. 15.

Braun, P. (2013). High white blood cell count. What you should knowfi Inside Tracker. Available at: Bunn, H. F. (2011). Approach to the anaemias. In: Goldman, L., Schaffer, A. I. eds. Cecil Medicine. 24th ed. Philadelphia, Pa: Saunders Elsevier, 161.

Casu, S., Boyazoglu J.G. \& Lauvergne J. J. (1970). The Inheritance of wattles in the Sardinian breed of sheep. Annales de Genetique et Selection Animale., 2, 249-261.

Chemocare (2019). Hypochloremia. chemocare.com/chemotherapy/sid eeffects/hypochloremia-lowchloride.aspx. retrieved 12 January, 2019.

Daramola, J. O., Adeloye, A. A., Fatoba, T. A. \& Soladoye, A. O. (2005). Haematological and serum biochemical parameters of West African Dwarf (WAD) goats. Livestock Research for Rural Development, 17(8). Available at: http://www.irrd.org/irrd17/8/dara1 7095.htm.

Dugdale, D. C. (2011). White Blood Cell Count. Medline Plus.

Etim, N. N., Enyenihi, G. E., Williams, M. E. Udo, M, D., \& Offiong, E. E. A. (2013). Haematological Parameters: Indicators of the Physi ological Status of Farm Animals. British Journal of Science, 10 (1), $37-47$. Federal University of
Technology Minna (2018). Student Hand book. Produced by Office of the Vice Chancellor Student Affairs Division. P1.

James, L. L. (2018). Hypertremia. MSD Manual Consumer version. https://www.msdmanuals.com/ho me/hormonal-and-metabolicdisorders/electrolytebalance/hypernatremia-high-levelof-sodium-in-the-blood.

Mayo Clinic (2018). High-density lipoprotein.

https://www.mayoclinic.org/diseas es-conditions/high-bloodcholesterol/in-depth/hdlcholesterol/art-20046388. October 24, 2018.

MedlinePlus (2018). The "Good" $\begin{array}{lllllllllllllllllll}\mathrm{C} & \mathrm{h} & \mathrm{o} & \mathrm{l} & \mathrm{e} & \mathrm{s} & \mathrm{t} & \mathrm{e} & \mathrm{r} & \mathrm{o} & \mathrm{l}\end{array}$. https://medlineplus.gov/hdlthegoo dcholester ol.html. 18 April, 2019.

Nemours Foundation (2018). Calcium. https://kidshealth.org/en/teens/cal cium.html.

Odubote, I. K. (1994). Characterization of West African Dwarf goat for certain qualitative trait. Nigerian Journal of Animal Production, 21, 37-41.

Osinowo, O. A., Buvanendram, V. \& Koning, M. L. (1988). A study of coat type, pigmentation and wattle incidence in Yankasa sheep and their effects on fertility and weaning weight. Proceedings of the $13^{\text {th }}$ Annual Conference of the Nigerian. Society of Animal Production, 18-23 March, 1988. University of Calabar, Nigeria.

Ozoje, M. O. and Mgbere, O. O. (2002). Coat pigmentation effects in West Africa Dwarf goats: Live weights and body dimensions. Nigerian Journal of Animal Production, 29(1), 5-10.

Preserved Article (2018). What is the 
importance of calcium in human bodyfi Retrieved from http://www.preservearticles.com/a rticles/what-is-the-importance-ofcalcium-in-human-body/5802.

Robert, A. V. (1994). Raising Healthy Goats under Primitive Conditions, Overview of General Information, Pp. 12-18. Christian Veterinary Mission, Washington, U.S.A.

SAS (2000). Statistical Analysis System. SAS Institute Inc, SAS Campus Drive. Carry, North Carolina 27513, U.S.A.

Shongjia, L., Xiangmo, L., Gangyl, X. and Shenov, C. (1992).
Relationship between physical traits, litter size and milk yield in Saanen, Guanzhong and Crossbred goats. Proceedings of the 5th International Conference of Goats. Pp. 83 in New Delhi.

Received: $11^{\text {th }}$ September, 2020 Accepted: $5^{\text {th }}$ January, 2021 